\title{
Thermal evaporation-oxidation deposited aluminum oxide as an interfacial modifier to improve the performance and stability of zinc oxide based planar perovskite solar cells.
}

Carlos A. Rodríguez-Castañeda ${ }^{* \dagger}$ Paola M. Moreno-Romero ${ }^{\dagger}$, Asiel N. Corpus-Mendoza ${ }^{\dagger}$, , Guillermo Suarez-Campos ${ }^{\dagger}$, Margarita Miranda-Hernández ${ }^{\dagger}$, Merida Sotelo-Lerma ${ }^{\ddagger}$, Hailin $\mathrm{Hu}^{* *, \dot{\dagger}}$

'Instituto de Energías Renovables - Universidad Nacional Autónoma de México, Priv. Xochicalco S/N, Temixco, Morelos, 62580, México.

${ }^{\S}$ CONACYT - Universidad Nacional Autónoma de México, 62580 Temixco, Morelos, Mexico

${ }^{\ddagger}$ Departamento de Investigación en Polímeros y Materiales, Universidad de Sonora, Blvd. Luis Encinas y Rosales s/n, Hermosillo, Sonora C.P. 83000, México

Corresponding Authors: *carc@ier.unam.mx,**hzh@ier.unam.mx

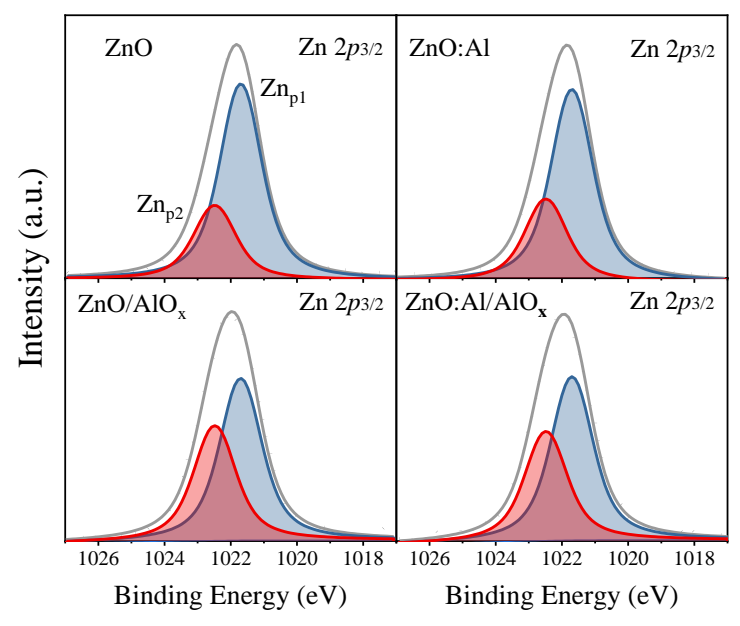

(a)

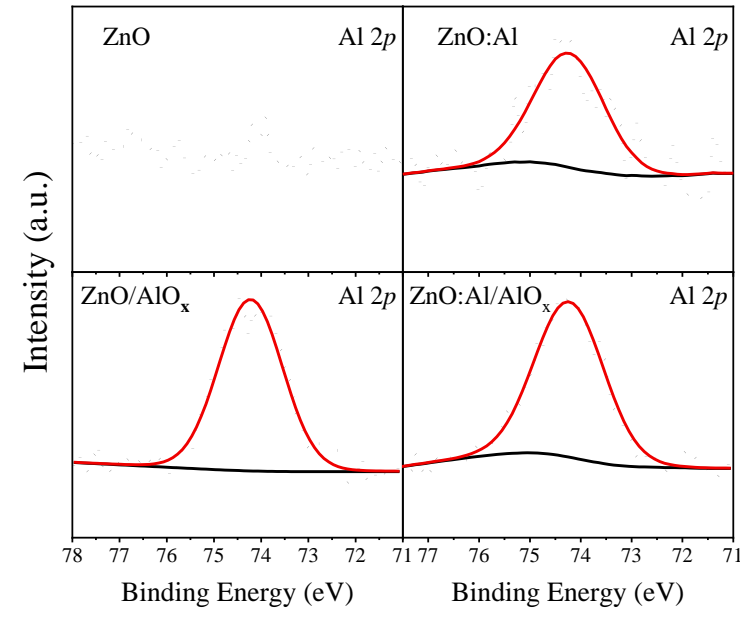

(b)

Figure S1. High resolution XPS spectra at (a) $\mathrm{Zn} 2 p_{3 / 2}$ and (b) Al $2 p$ binding energy regions of the surface of the four $\mathrm{ZnO}$ films. 


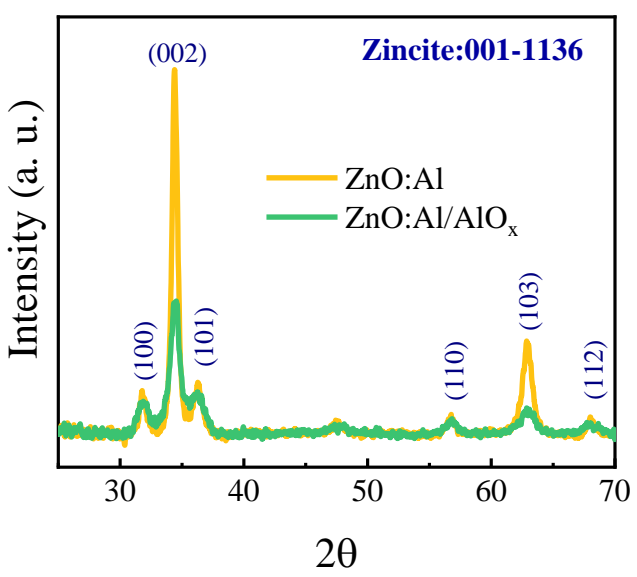

(a)

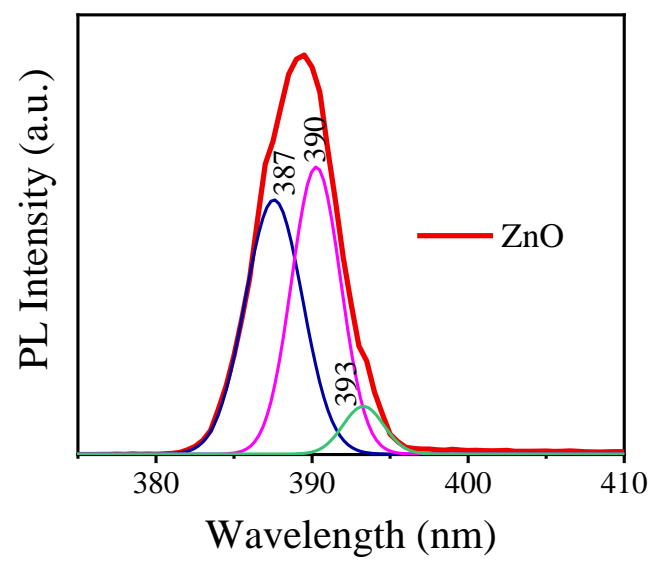

(c)

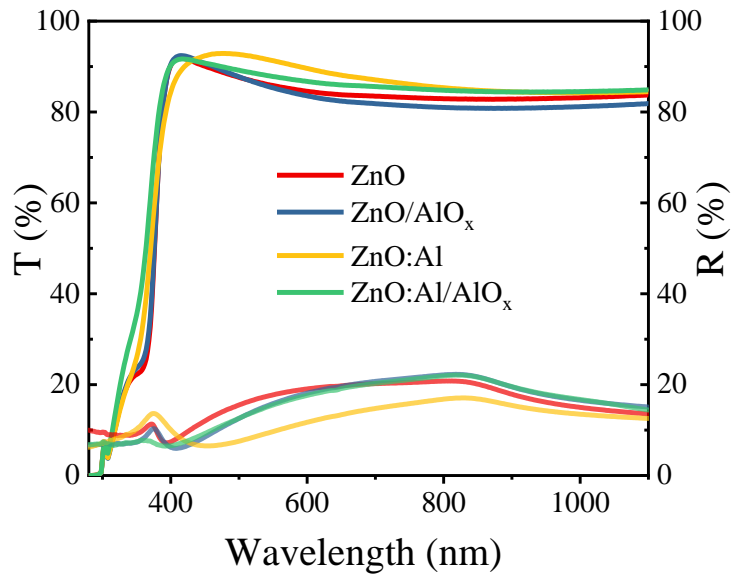

(b)

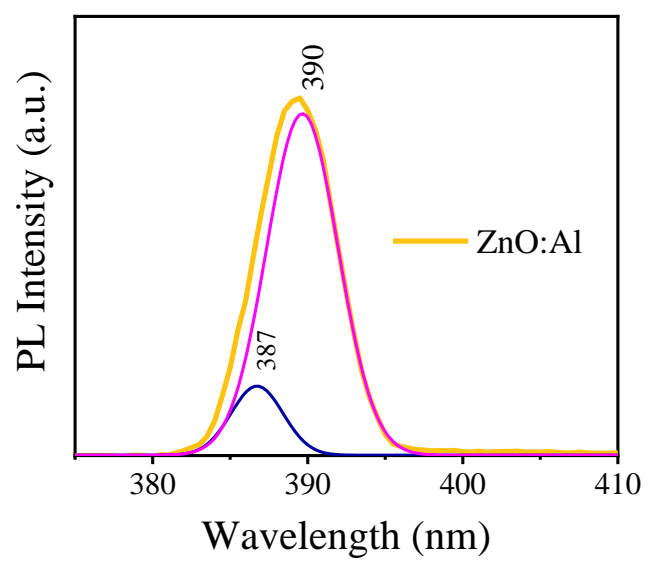

(d)

Figure S2. (a) XRD patterns of $\mathrm{ZnO}: \mathrm{Al}$ and $\mathrm{ZnO}: \mathrm{Al} / \mathrm{AlO}_{\mathrm{x}}$ films. (b) Transmittance (T) and reflectance (R) spectra of the four types of $\mathrm{ZnO}$ films. (c) Photoluminescence spectrum of $\mathrm{ZnO}$ thin film. (d) Photoluminescence spectrum of $\mathrm{ZnO}: \mathrm{Al}$ thin film.

Using the transmittance $(T)$ and reflectance $(R)$ spectra and thickness $(d)$ values, the absorption coefficient $(\alpha)$ spectra of $\mathrm{ZnO}$ films are calculated by using the following equation [S1]:

$\alpha=-\frac{1}{d} \ln \left(\frac{-(1-R)^{2}+\sqrt{(1-R)^{4}+4 T^{2} R^{2}}}{2 T R^{2}}\right)$

The electrical properties of $\mathrm{ZnO}$ films are determined through the following relations [S1]: 
Resistance $R$ :

$R=\frac{V}{I}$

Resistivity $\rho$ :

$\rho=R \cdot \frac{w \cdot t}{L}$

In Eq.2 and 3, the unit of $R$ is Ohms, that of the current $I$ is in Ampere, $V$ is the applied voltage of the sample in Volts. In Eq.3, $\rho$ is the resistivity, $w$ is the electrode length, $t$ is the film thickness and $L$ is the separation between the two parallel electrodes. The conductivity $\sigma$ of $\mathrm{ZnO}$ films is calculated as follows:

$\sigma=\frac{1}{\rho}$
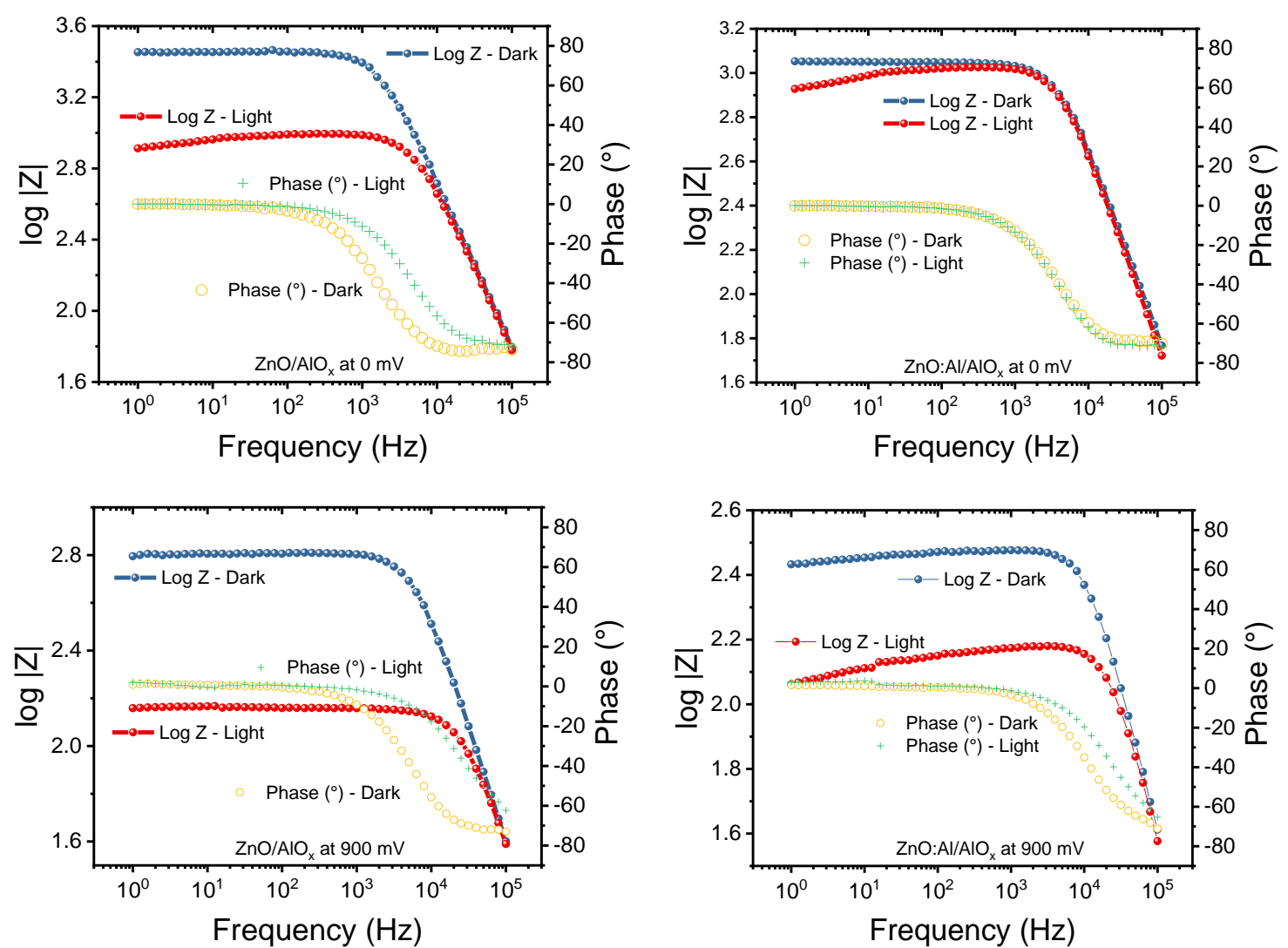

Figure S3. Bode diagrams at $0 \mathrm{~V}$ in dark and under illumination, at $900 \mathrm{mV}$ in dark and under illumination of $\mathrm{ZnO} / \mathrm{AlO}_{\mathrm{x}}$ and $\mathrm{ZnO}: \mathrm{Al} / \mathrm{AlO}_{\mathrm{x}}$ samples. 


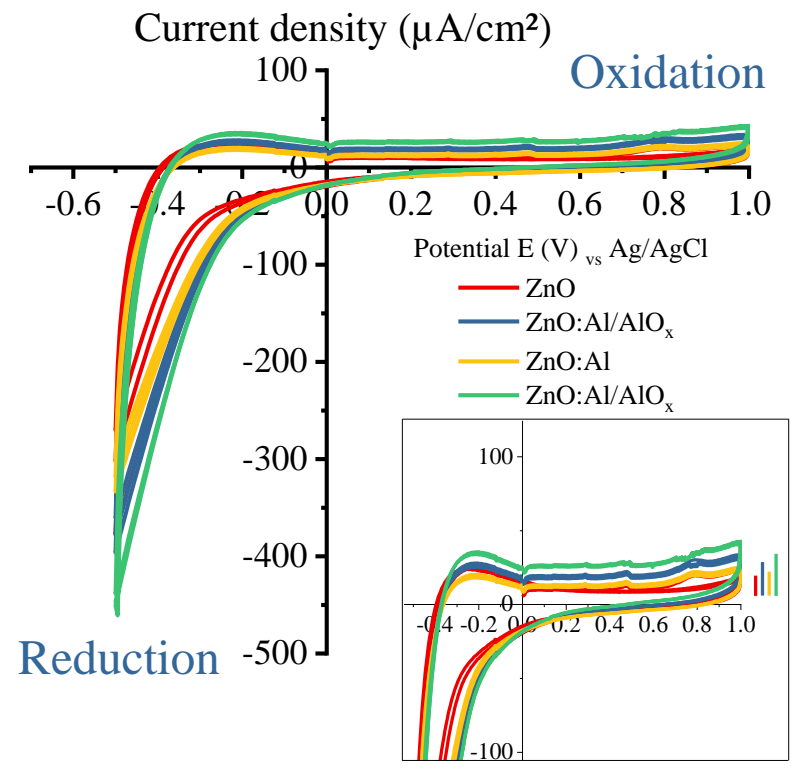

Figure S4. Cyclic voltammetry (CV) curves of the four $\mathrm{ZnO}$ samples in an electrolyte of $0.1 \mathrm{M}$ $\left(\mathrm{CH}_{3} \mathrm{CH}_{2} \mathrm{CH}_{2} \mathrm{CH}_{2}\right)_{4} \mathrm{~N}\left(\mathrm{PF}_{6}\right)$ in acetonitrile.
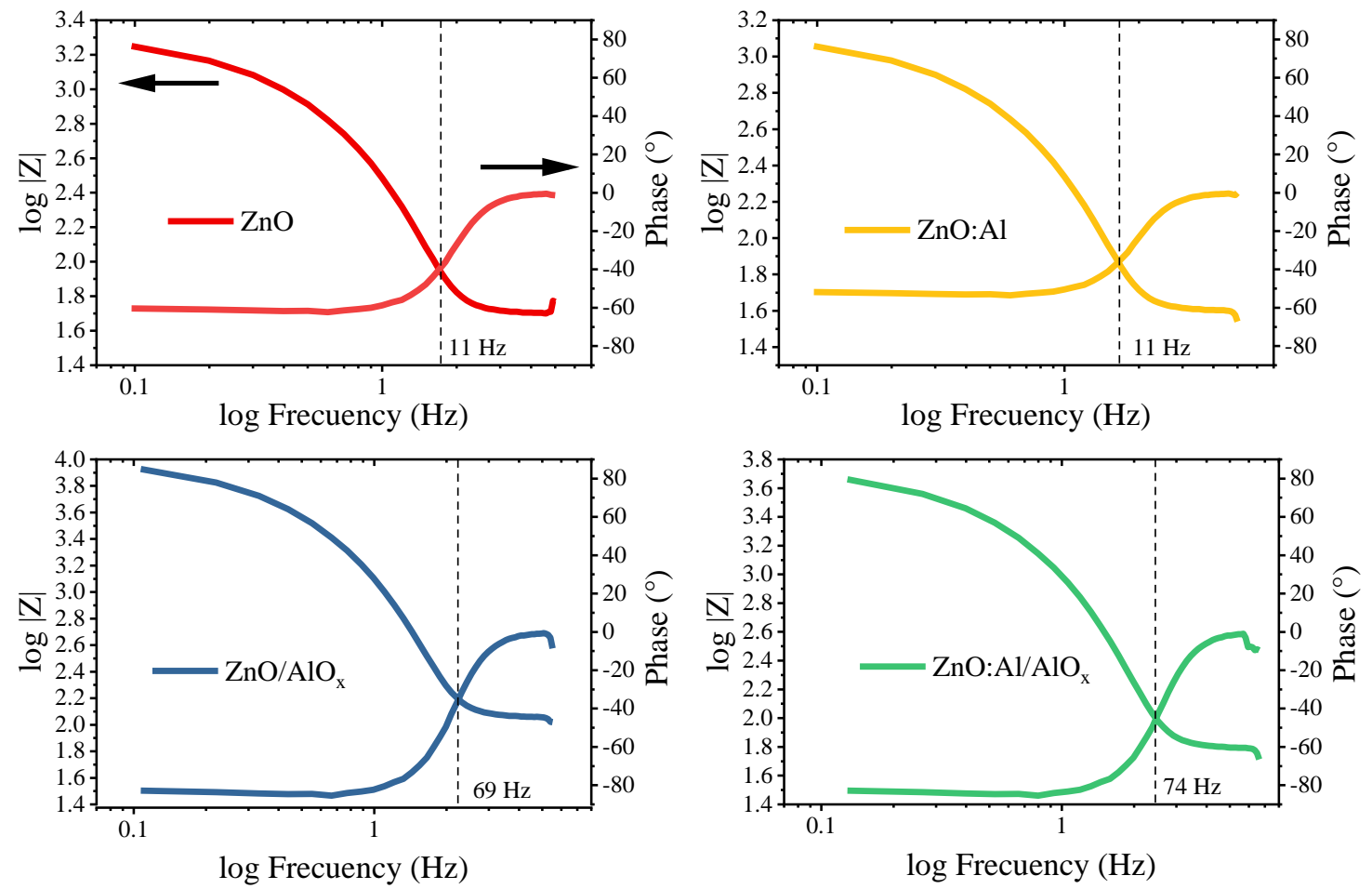

Figure S5. Electrochemical impedance spectroscopy measurements of the four $\mathrm{ZnO}$ samples. 
Calculation for $\boldsymbol{E}_{\mathrm{C}}-\boldsymbol{E}_{\mathrm{F}}$ :

For a n-type semiconductor, the Fermi level $\mathrm{E}_{\mathrm{F}}$ can be described as:

$E_{F}=E_{F 0}+k_{B} T \ln \left(\frac{N_{D}}{N_{i}}\right)$

where $E_{F 0}$ and $N_{i}$ is the Fermi level and impurity concentration of the intrinsic semiconductor, respectively, $k$ is the Boltzmann constant and $T$ the absolute temperature. It is evident that for each type of semiconductor at the same temperature, its Fermi level depends on the concentration of dopant, $N_{D}$. It is reported that polycrystalline $\mathrm{ZnO}$ thin films prepared by atomic layer deposition with an $N_{D}$ of about $10^{18} \mathrm{~cm}^{-3}$ give a difference between the conduction band edge $\left(E_{C}\right)$ and Fermi level (we will call it as $E_{F 18}$ ) of about $0.04 \mathrm{eV}$ at room temperature [S2]. By using Eq.5,

$E_{C}-E_{F 18}=0.04(e V)=E_{C}-\left\{E_{F 0}+k T \ln \left(\frac{10^{18}}{N_{i}}\right)\right\}$

Considering that:

$\ln \left(\frac{10^{18}}{N_{i}}\right)=\ln \left(\frac{10^{17}}{N_{i}}\right)+\ln (10)=\ln \left(\frac{10^{16}}{N_{i}}\right)+\ln \left(10^{2}\right)$,

we can estimate the $E_{C}-E_{F}$ values of the four types of $\mathrm{ZnO}$ by assuming that the $N_{i}$ value is independent on the $\mathrm{ZnO}$ preparation process. The obtained values are listed in Table $\mathrm{S} 1$ by using the following deduction:

$$
\begin{aligned}
0.04 & =E_{C}-\left\{E_{F 0}+k T \ln \left(\frac{10^{18}}{N_{i}}\right)\right\} \\
& =E_{C}-\left\{E_{F 0}+k T\left\{\ln \left(\frac{9.109 \times 10^{16}}{N_{i}}\right)+\ln (10.978)\right\}\right\}=E_{C}-E_{F, Z n O}-0.062 \\
& =E_{C}-\left\{E_{F 0}+k T\left\{\ln \left(\frac{7.621 \times 10^{16}}{N_{i}}\right)+\ln (13.122)\right\}\right\}=E_{C}-E_{F, Z n O / A l O x}-0.066 \\
& =E_{C}-\left\{E_{F 0}+k T\left\{\ln \left(\frac{1.093 \times 10^{17}}{N_{i}}\right)+\ln (9.148)\right\}\right\}=E_{C}-E_{F, Z n O: A l}-0.057
\end{aligned}
$$




$$
=E_{C}-\left\{E_{F 0}+k T\left\{\ln \left(\frac{7.128 \times 10^{16}}{N_{i}}\right)+\ln (14.029)\right\}\right\}=E_{C}-E_{F, \text { Zno:al } / \text { Alox }}-0.068
$$

Consequently,

$$
\begin{gathered}
E_{C}-E_{F, Z n o}=0.102 \mathrm{eV} \\
E_{C}-E_{F, Z n O / A l O x}=0.106 \mathrm{eV} \\
E_{C}-E_{F, Z n O: A l}=0.097 \mathrm{eV} \\
E_{C}-E_{F, \text { Zno:al } / \text { Alox }}=0.108 \mathrm{eV}
\end{gathered}
$$

\begin{tabular}{|c|c|c|c|c|c|c|}
\hline Sample & $\begin{array}{c}V_{\mathrm{FB}(\mathrm{Ag} / \mathrm{AgCl})} \\
(\mathrm{V})^{*}\end{array}$ & $N_{\mathrm{D}}\left(\mathrm{cm}^{-3}\right)^{*}$ & $\begin{array}{c}E_{\mathrm{F}} \\
(\mathrm{eV})\end{array}$ & $\begin{array}{c}E_{C}-E_{F} \\
(e V)\end{array}$ & $\begin{array}{c}E_{\mathrm{C}} \\
(\mathrm{eV})\end{array}$ & $\begin{array}{c}E_{\mathbf{V}} \\
(\mathrm{eV})\end{array}$ \\
\hline $\mathrm{ZnO}$ & 0.165 & $9.109 \times 10^{16}$ & -4.58 & 0.10 & -4.48 & -7.62 \\
\hline $\mathrm{ZnO} / \mathrm{AlO}_{\mathrm{x}}$ & 0.079 & $7.621 \times 10^{16}$ & -4.49 & 0.11 & -4.38 & -7.52 \\
\hline $\mathrm{ZnO}: \mathrm{Al}$ & 0.146 & $1.093 \times 10^{17}$ & -4.56 & 0.10 & -4.46 & -7.62 \\
\hline $\mathrm{ZnO}: \mathrm{Al} / \mathrm{AlO}_{\mathrm{x}}$ & 0.057 & $7.128 \times 10^{16}$ & -4.47 & 0.11 & -4.36 & -7.52 \\
\hline
\end{tabular}

Table S1. Flat-band, charge carrier concentration and electronic levels of $\mathrm{ZnO}, \mathrm{ZnO} / \mathrm{AlO}_{\mathrm{x}}, \mathrm{ZnO}: \mathrm{Al}$ and $\mathrm{ZnO}: \mathrm{Al} / \mathrm{AlO}_{\mathrm{x}}$ films.

${ }^{*} \varepsilon=8$ to 10.9 , depending on the range frequency measurement and film deposition process of $\mathrm{ZnO}$ [S3-S6].

The hysteresis phenomenon in a solar cell can be quantified with the hysteresis index $(H I)$, defined as follows [S7]:

$$
H I=\frac{\int_{0}^{V_{O C}} J_{(r)} \mathrm{dV}-\int_{0}^{V O C} J_{(f)} d V}{\int_{0}^{V O C} J_{(r)} d V} \times 100 \%
$$


where $J_{(r)}$ is the current density measured in the reverse direction, and $J_{(f)}$, the current density measured at forward direction.

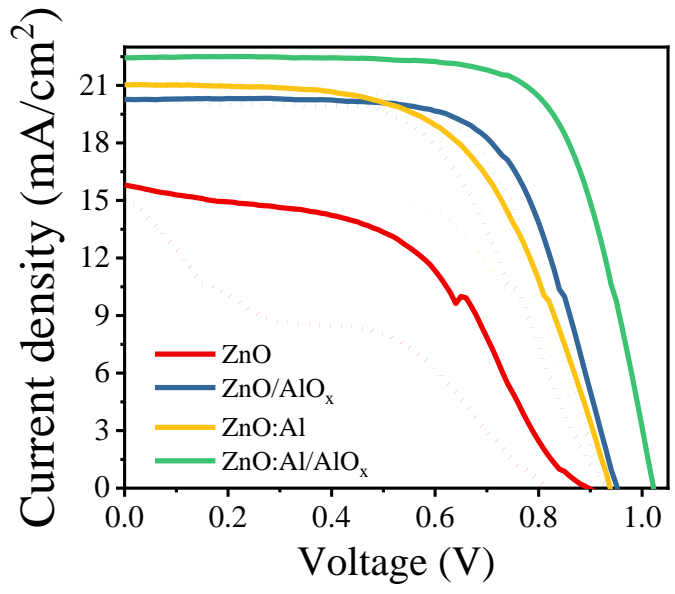

\begin{tabular}{cccccc}
\hline Sample & $\int_{0}^{V o c} J(r)$ & $\int_{0}^{V o c} J(f)$ & HI (\%) & $\begin{array}{c}\text { PCE } \\
(\%) \\
\text { Forward }\end{array}$ & $\begin{array}{c}\text { PCE } \\
(\%) \\
\text { Reverse }\end{array}$ \\
\hline $\mathrm{ZnO}$ & 10.19 & 6.45 & 36.68 & 4.06 & 6.46 \\
$\mathrm{ZnO} / \mathrm{AlO}_{\mathrm{x}}$ & 16.77 & 14.96 & 10.79 & 10.74 & 12.07 \\
$\mathrm{ZnO}: \mathrm{Al}$ & 16.33 & 11.96 & 19.79 & 8.75 & 10.47 \\
$\mathrm{ZnO}: \mathrm{Al} / \mathrm{AlO}_{\mathrm{x}}$ & 20.59 & 16.51 & 26.78 & 12.22 & 16.49 \\
\hline
\end{tabular}

Figure S6. Reverse and forward $J$ - $V$ curves and hysteresis index (HI) of freshly prepared $\mathrm{ZnO}, \mathrm{ZnO} / \mathrm{AlO}_{\mathrm{x}}$, $\mathrm{ZnO}: \mathrm{Al}$ and $\mathrm{ZnO}: \mathrm{Al} / \mathrm{AlO}_{\mathrm{x}}$ based PSCs. 
(a)

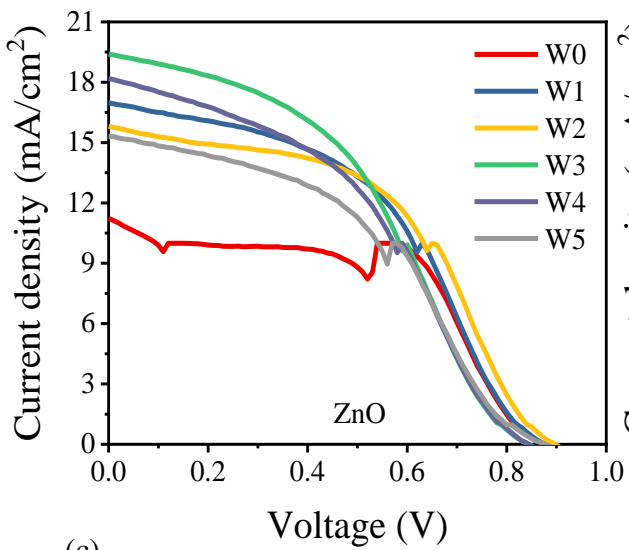

(c)

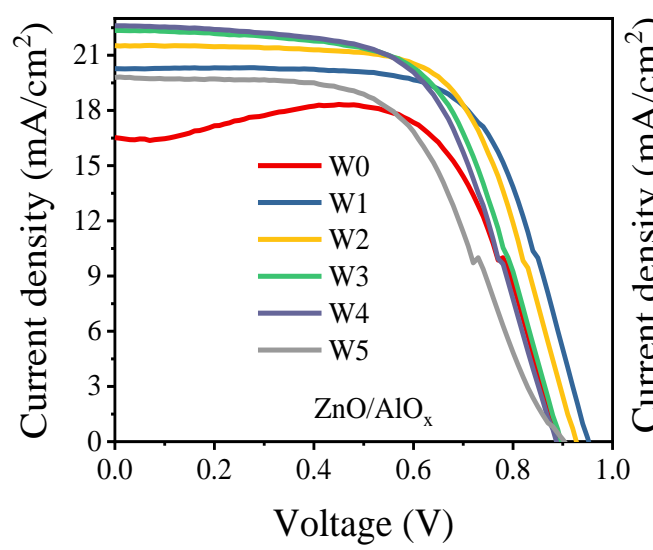

(b)

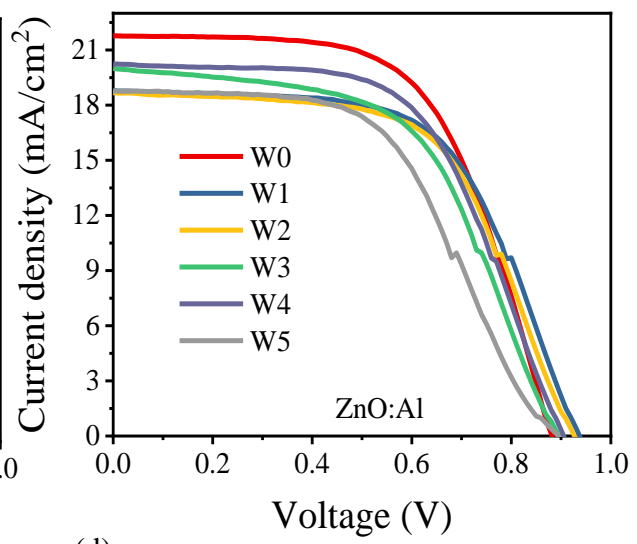

(d)

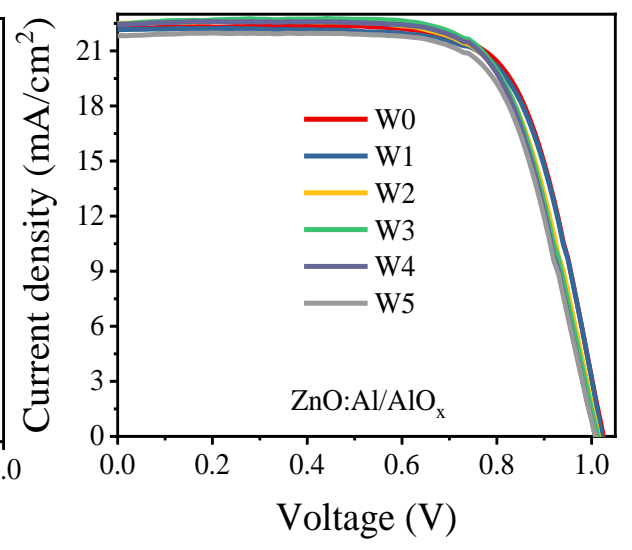

Figure S7. $J-V$ curves of 5 freshly prepared perovskite solar cell samples for each type of $\mathrm{ZnO}$ :

(a) $\mathrm{ZnO}$, (b) $\mathrm{ZnO}: \mathrm{Al}$, (c) $\mathrm{ZnO} / \mathrm{AlO}_{\mathrm{x}}$ and (d) $\mathrm{ZnO}: \mathrm{Al} / \mathrm{AlO}_{\mathrm{x}}$ modified films. 
(a)
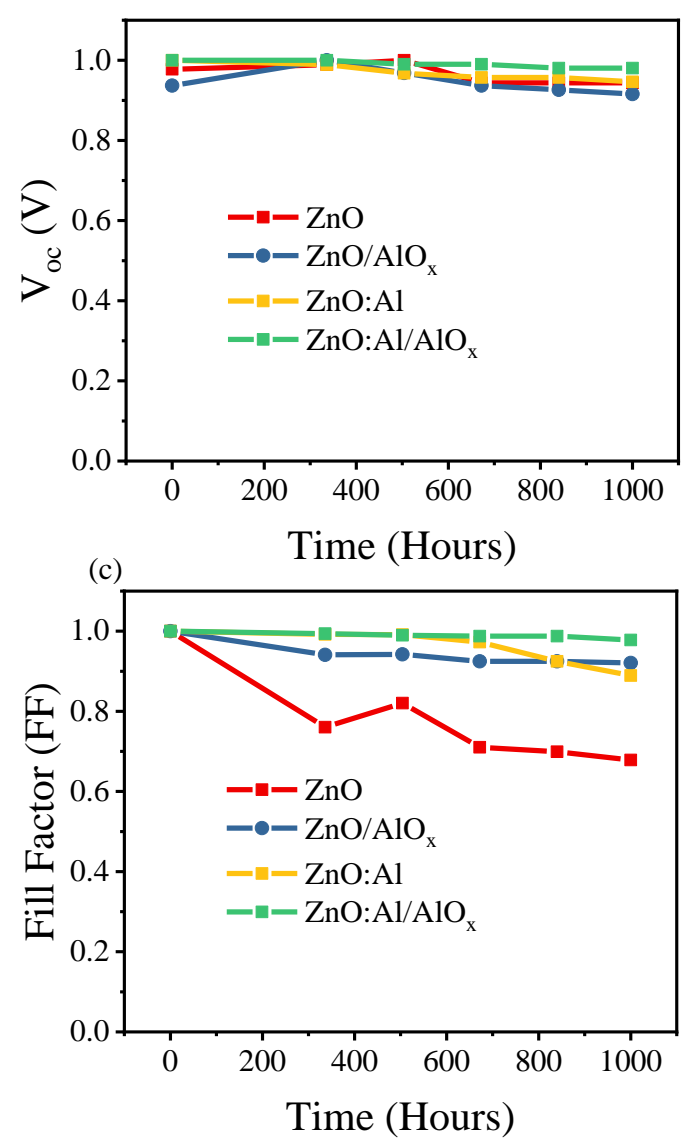

(b)
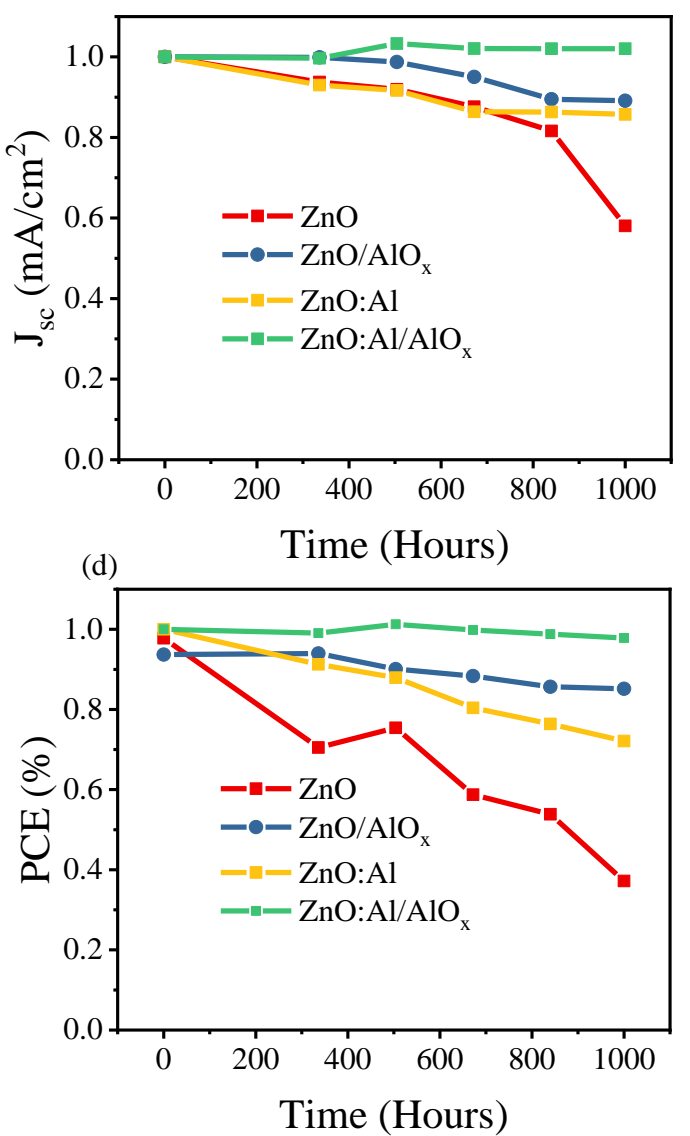

Figure S8. Photovoltaic parameters of $\mathrm{ZnO}, \mathrm{ZnO}: \mathrm{Al}, \mathrm{ZnO} / \mathrm{AlO}_{\mathrm{x}}$ and $\mathrm{ZnO}: \mathrm{Al} / \mathrm{AlO}_{\mathrm{x}}$ based $\mathrm{PSCs}$ as a function of shelf life time (storage time) in ambient conditions.

\section{References:}

(S1) Schroder, D.K. Semiconductor Material and Device Characterization, Wiley \& Sons, 3, 2006, 585-590.

(S2) Kwietniewski, N.; Masłyk, M.; Werbowy, A.; Taube, A.; Gierałtowska, S.; Wachnicki, Ł.; Sochacki, M. Electrical characterization of $\mathrm{ZnO} / 4 \mathrm{H}-\mathrm{SiC} \mathrm{n}-\mathrm{p}$ heterojunction diode. Phys. Status Solidi A 2016, 213, 1120-1124.

(S3) Gelderman, K.; Lee, L.; Donne, S. W. Using the Mott-Schottky Equation: Using the Mott-Schottky Equation. J. Chem. Educ. 2007, 84, 685.

(S4) Alexander, T. P.; Bukowski, T. J.; Uhlmann, D. R.; Teowee, G.; McCarthy, K. C.; Dawley, J.; Zelinski, B. J. J. Dielectric Properties of Sol-Gel Derived ZnO Thin Films. In 
ISAF '96. Proceedings of the Tenth IEEE International Symposium on Applications of Ferroelectrics; IEEE, 1996, 2, 585-588.

(S5) Crisler, D. F.; Cupal, J. J.; Moore, A. R. Dielectric, Piezoelectric, and Electromechanical Coupling Constants of Zinc Oxide Crystals. Proc. IEEE 1968, 56, 225226.

(S6) Langton, N. H.; Matthews, D. The Dielectric Constant of Zinc Oxide over a Range of Frequencies. Br. J. Appl. Phys. 1958, 9, 453-456.

(S7) Lee J. W.; Kim S. G.; Bae S. H.; Lee D. K.; Lin O.; Yang Y.; Park N. G. the interplay between trap density and hysteresis in planar heterojunction perovskite solar cells. Nano Lett. 2017, 17, 4270-4276. 